\title{
PENGARUH MOTIVASI DAN PERSEPSI KUALITAS TERHADAP MINAT BELI LAPTOP PADA MAHASISWA TANGERANG
}

\author{
Adhi Satrio, Gracia Rachmi Adiarsi \\ adhistr@,gmail.com \\ Sekolah Tinggi Ilmu Komunikasi London School of Public Relations
}

\begin{abstract}
The development of information technology makes it easy for community members to interact with other members of society not limited to space and time. The producers create various forms of computers which are technological tools to facilitate communication. Desktops, laptops or notebooks with various brands on the market. The public is faced with offering laptop brands such as Apple, Asus, Acer, Dell, Lenovo, HP, and other brands. Based on data on global laptop shipments in 2017 there were 164.7 million units. The Apple brand outperformed Asus and won 4th place the previous year ranking 5. The success of Apple with Macbook Pro products in 2017 showed an increase in buying interest in Apple laptops. This is inseparable from Apple's laptop products perceived quality and meet what consumers want from a brand. The purpose of this study is to see whether motivation and perceived quality affect buying interest in Apple laptops and analyze the influence of motivation and perceived quality on interest in buying Apple laptops. The theory used is motivation theory, perceived quality, buying interest. The method used is a quantitative method by collecting data through a questionnaire. Based on the results of the study, it was found that motivation and perceived quality had a significant effect on buying Apple brand laptops. Motivation and perceived quality simultaneously have a significant effect on buying Apple brand laptops with students from private universities in Tangerang
\end{abstract}

Keywords: Apple Laptop, Motivation, Perception of Quality, Buying interest

\begin{abstract}
ABSTRAK
Perkembangan teknologi informasi memudahkan anggota masyarakat berinteraksi dengan anggota masyarakat lainnya tidak terbatas dengan ruang dan waktu. Para produsen menciptakan berbagai bentuk komputer yang merupakan sarana teknologi untuk memudahkan komunikasi. Desktop, laptop atau notebook dengan berbagai merek beredar dipasaran. Masyarakat berhadapan dengan penawaran merek laptop seperti Apple, Asus, Acer, Dell, Lenovo, HP, dan merek lainnya. Berdasarkan data pengiriman laptop secara global tahun 2017 tercatat 164,7 juta unit. Merek Apple mengungguli Asus dan meraih posisi ke-4 yang tahun sebelumnya peringkat ke 5. Keberhasilan Apple dengan produk Macbook Pro di tahun 2017 memperlihatkan adanya peningkatan minat beli terhadap laptop Apple. Hal tersebut tidak terlepas dari produk laptop keluaran Apple dipersepsikan berkualitas dan memenuhi apa yang konsumen inginkan dari sebuah merek. Tujuan dari penelitian ini adalah melihat apakah motivasi dan persepsi kualitas memengaruhi minat beli pada laptop Apple dan menganalisis pengaruh motivasi dan persepsi kualitas terhadap minat beli laptop Apple. Adapun teori yang digunakan adalah teori motivasi, persepsi kualitas, minat beli. Metode yang digunakan adalah metode kuantitatif dengan pengumpulan data melalui kuesioner. Berdasarkan hasil penelitian didapat motivasi dan persepsi kualitas berpengaruh signifikan terhadap minat beli laptop merek Apple. Motivasi dan persepsi kualitas secara simultan berpengaruh signifikan terhadap minat beli laptop merek Apple pada mahasiswa perguruan tinggi swasta di Tangerang.
\end{abstract}

Kata Kunci: Laptop Apple, Motivasi, Persepsi Kualitas, Minat Beli 


\section{PENDAHULUAN}

Pada era globalisasi saat ini, perkembangan teknologi informasi memang tidak bisa dibendung lagi. Teknologi yang semakin canggih sangat membantu dan memudahkan masyarakat. Kegiatan sehari-hari masyarakat tidak lepas dengan kehadiran teknologi yang membuat seseorang berinteraksi dengan orang lain tidak terbatas jarak dan waktu.

Masyarakat dapat dengan mudah berkomunikasi dengan orang lain di mana dan kapan saja. Banyak sarana teknologi yang membantu kita mencapai itu, salah satunya adalah komputer. Menurut Williams dan Stacey (2011) komputer adalah programmable, mesin serbaguna yang menerima data mentah fakta dan angka-angka dan proses, atau memanipulasi, menjadi informasi yang bisa kita gunakan, seperti ringkasan, total, atau laporan.

Komputer terdiri atas dua bagian, yang pertama adalah perangkat keras yang meliputi layar, Central Processing Unit (CPU), memori, dan sebagainya, kemudian perangkat lunak yang meliputi aplikasi dan sistem operasi.

Komputer desktop biasa digunakan untuk mengerjakan tugastugas kantor maupun kuliah. Akan tetapi, karena komponennya yang berukuran besar seperti layar dan CPU, sangat tidak memungkinkan untuk membawanya kemana pun. Maka dari itu, seiring berjalannya waktu dan berkembang pesatnya teknologi membuat diciptakannya komputer dalam bentuk yang lebih minimalis dengan spesifikasi yang sama atau bahkan lebih canggih dari komputer desktop, yang sekarang biasa disebut dengan laptop, atau notebook.

Laptop atau komputer jinjing sendiri memiliki ukuran yang lebih kecil dan ringan, dengan kesamaan komponen di dalamnya dengan komputer desktop yang dibuat lebih kecil agar menyesuaikan dengan bentuknya yang ringkas. Oleh karena itu, kalangan masyarakat sekarang yang beralih menggunakan laptop untuk mendukung mobilitas seharihari.

Laptop yang sudah dianggap bukan barang mewah memang dapat dikatakan menjadi barang primer saat ini dan menjadi kebutuhan bagi berbagai macam kalangan masyarakat, mulai dari pelajar, mahasiswa, karyawan, hingga pengusaha atau konglomerat yang menggunakannya untuk membantu menjalankan dan memberi kemudahan mereka melakukan aktivitas pekerjaan setiap harinya.

Seiring dengan berjalannya waktu dan berkembangnya teknologi, penggunaan laptop bukan lagi 
sekedar alat ketik dan menyimpan data-data, tetapi dapat digunakan untuk mengakses berbagai macam informasi pada portal berita, bermain games secara offline maupun online, dan bahkan dijadikan sarana untuk berjualan dan berbelanja kebutuhan sehari-hari secara online.

Menurut data yang didapatkan dari lembaga riset Nielsen pada tahun 2017 dalam surveinya mengenai "Tren terbaru dikalangan masyarakat
Indonesia, bagaimana dan di mana konsumen digital mengakses konten online" menyebutkan bahwa terjadi peningkatan penggunaan laptop untuk mengakses konten digital di tahun 2017 menjadi 74\%, menduduki posisi ke-2 setelah ponsel pintar dan unggul dari penggunaan komputer untuk mengakses konten digital yang sebesar 59\%. Grafik tersebut dapat dilihat pada Gambar 1 di bawah ini.

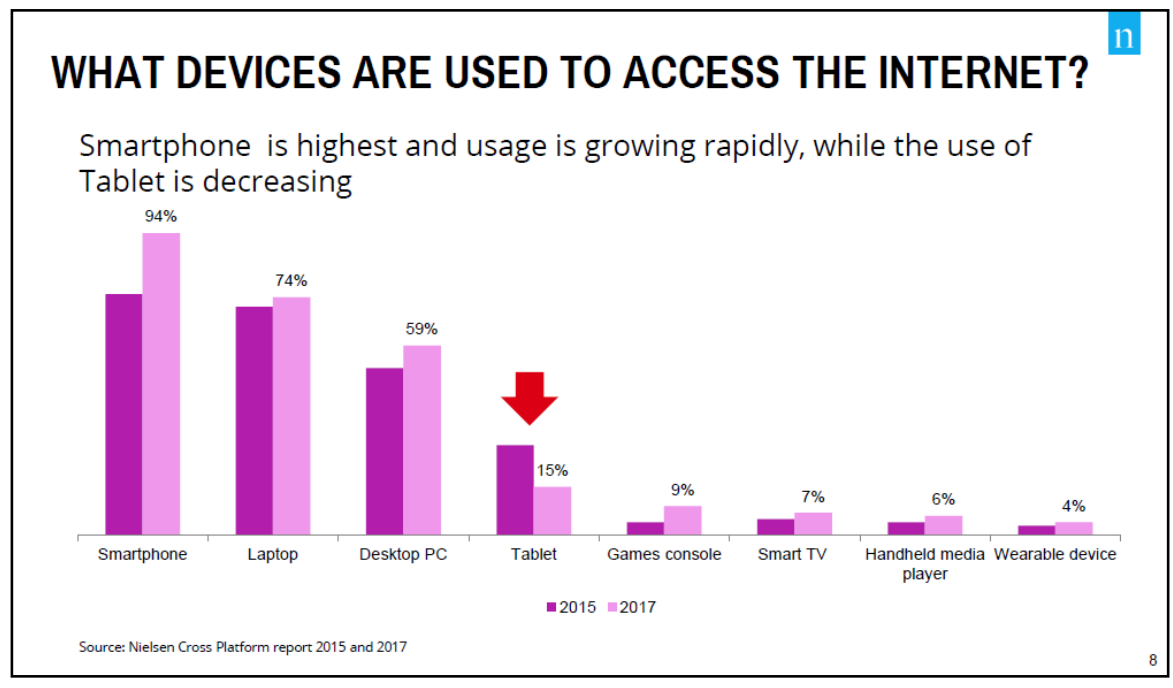

Gambar 1 Grafik Penggunaan Alat Untuk Mengakses Internet Sumber: Survei Nielsen (2017)

Dengan melihat kebutuhan akan laptop dikalangan masyarakat, para produsen berlomba untuk dapat memproduksi laptop dengan berbagai merek dan jenis. Produsen laptop harus secara tanggap untuk melihat dan melakukan pengamatan terhadap apa yang diinginkan konsumen dari sebuah laptop buatan mereka.
Menurut Wibowo dan Supriadi (2013) faktor-faktor yang memengaruhi keputusan pembelian konsumen adalah faktor internal (faktor pribadi) dan faktor eksternal. Faktor internal yang dapat memengaruhi perilaku konsumen, yaitu motivasi dan persepsi. Dewasa ini, masyarakat dihadapkan dengan 
sejumlah merek laptop yang beredar dipasaran, seperti Apple, Asus, Acer, Dell, Lenovo, HP, dan merek lainnya. Data yang dikeluarkan dari sebuah perusahaan riset pasar TrendForce yang didapatkan dari situs press.trendforce.com, melaporkan bahwa pengiriman laptop secara global pada tahun 2017 mencatatkan 164,7 juta unit, mengalami pengikatan sebanyak $2,1 \%$ dari tahun sebelumnya yang hanya 161,2 juta unit dan $0,7 \%$ lebih besar dari perkiraan. Data tersebut dapat dilihat pada Gambar 2 di bawah.

\begin{tabular}{|c|c|c|c|c|c|c|}
\hline \multirow{2}{*}{ Company } & \multicolumn{2}{|c|}{2016} & \multicolumn{2}{|c|}{2017} & \multicolumn{2}{|c|}{$2018(E)$} \\
\hline & Ranking & Market Share & Ranking & Market Share & Ranking & Market Share \\
\hline HP & 1 & $22.4 \%$ & 1 & $24.3 \%$ & 1 & $24.4 \%$ \\
\hline Lenovo & 2 & $21.7 \%$ & 2 & $20.2 \%$ & 2 & $20.8 \%$ \\
\hline Dell & 3 & $15.4 \%$ & 3 & $15.2 \%$ & 3 & $15.6 \%$ \\
\hline ASUS & 4 & $10.3 \%$ & 5 & $9.5 \%$ & 5 & $9.8 \%$ \\
\hline Apple & 5 & $8.3 \%$ & 4 & $9.6 \%$ & 4 & $10.4 \%$ \\
\hline Acer & 6 & $8.1 \%$ & 6 & $8.0 \%$ & 6 & $8.2 \%$ \\
\hline Other & & $13.8 \%$ & & $13 \%$ & & $11 \%$ \\
\hline $\begin{array}{c}\text { Total Shipment } \\
\text { (in million) }\end{array}$ & \multicolumn{2}{|c|}{161.2} & \multicolumn{2}{|c|}{164.7} & \multicolumn{2}{|c|}{163.8} \\
\hline
\end{tabular}

\section{Gambar 2 Tabel Pengiriman Laptop Seluruh Dunia Tahun 2017}

Sumber: press.trendforce.com

Dapat dilihat pada gambar di atas bahwa HP dengan pangsa pasar sebesar 24,3\%, memegang posisi pertama dalam pasar laptop seluruh dunia pada tahun 2017. Sementara itu, laptop Apple dapat mengungguli Asus dan meraih posisi ke-4 dengan pangsa pasar $9,6 \%$. Sedangkan untuk beberapa merek lainnya seperti Lenovo, Dell, dan Acer mengalami penurunan dalam pangsa pasar global.

Pencapaian Apple tersebut disebabkan oleh pembaharuan dari produk laptop unggulan mereka, yaitu Apple Macbook Pro pada kuartal ke 2 tahun 2017 yang membantu pengiriman laptop Apple hingga 18\% untuk keseluruhan tahun dan merupakan pertumbuhan yang terbesar diantara semua merek laptop. Kesuksesan Apple dengan produk Macbook Pro di tahun 2017 membuktikan bahwa minat beli terhadap laptop Apple meningkat, hal tersebut tidak lepas dari Apple yang mengeluarkan produk laptop yang dipersepsikan berkualitas dan memenuhi apa yang konsumen inginkan dari sebuah merek Apple, sehingga konsumen termotivasi membeli laptop merek tersebut dan 
kualitas yang dipersepsikan oleh konsumen terhadap merek tersebut merupakan persepsi yang baik.

Beberapa situs ulasan laptop memberikan penilaian terhadap laptop Apple, salah satunya menurut situs atulhost.com, merek laptop yang Laptop keluaran Apple terkenal dengan kualitas dan hadir dengan fitur-fitur yang mudah digunakan (Atulhost, 2017). Menurut techlogitic.net, laptop keluaran Apple merupakan produk terbaik jika konsumen membutuhkan perpaduan yang sempurna dalam hal kemudahan, performa, dan daya tahan baterai, meskipun konsumen harus membayar mahal untuk membelinya, dan juga tidak tersedianya banyak port pada produknya (McKinney, 2017).

Dalam artikel berjudul "Pasar Laptop Indonesia Naik Walau Digempur Smartphone" pada situs inet.detik.com menjelaskan bahwa data penjualan laptop di Indonesia yang didapat dari lembaga riset IDC Indonesia mencapai angka 3,9 juta unit. Hasil tersebut lebih besar 100 ribu unit dari perkiraan para analis pasar dan terjadi peningkatan sebesar $11 \%$ dibandingkan dengan tahun 2016 akibat dari melonjaknya penjualan perangkat laptop di kelas konsumen. Dapat disimpulkan bahwa pasar laptop di Indonesia mengalami peningkatan walaupun tidak besar, dan tidak disebutkan berapa persen menduduki peringkat pertama sebagai "10 Best Laptop Brands 2017" adalah merek Apple, dengan produk Macbook Pro. Apple membuat produk yang revolusioner, dan inovatif mengungguli merekmerek lainnya.

pangsa pasar dari masing-masing merek laptop yang ada di Indonesia.

Berangkat dari fenomena yang terjadi pada meningkatnya pengiriman laptop Apple pada tahun 2017 secara global, pendapat dari beberapa situs ternama mengenai kualitas produk laptop Apple, dan peningkatan penjualan laptop di Indonesia, peneliti ingin menguji apakah motivasi dan persepsi kualitas memengaruhi minat beli pada laptop Apple dan menganalisis pengaruh motivasi dan persepsi kualitas terhadap minat beli laptop Apple pada mahasiswa di salah satu perguruan tinggi swasta di Tangerang.

Berdasarkan latar belakang yang sudah dikemukakan tersebut, maka rumusan masalah yang dapat diambil dari penelitian ini adalah apakah ada pengaruh motivasi dan persepsi kualitas terhadap minat beli laptop merek Apple dan seberapa besar pengaruh motivasi serta persepsi kualitas terhadap minat beli laptop merek Apple pada mahasiswa di salah satu perguruan tinggi swasta di Tangerang.

Motivasi adalah suatu dorongan yang membuat konsumen 
ingin membeli. Hal ini dipicu oleh tekanan psikologis yang disebabkan oleh tidak terpenuhinya suatu kebutuhan. Individu-individu tersebut berusaha secara sadar maupun tidak sadar untuk mengurangi tekanan ini melalui pemilihan apa yang menjadi tujuannya. Selanjutnya dengan berperilaku tersebut mereka berharap dapat terbebas dari tekanan dan terpenuhi kebutuhannya. (Schiffman dan Wisenblit, 2014).

Terdapat dua jenis motivasi, yaitu motivasi rasional dan motivasi emosional. Menurut Schiffman \& Kanuk dalam Yusa (2015) yang dimaksud dengan motivasi rasional ialah motivasi yang didasarkan pada fakta-fakta dimana tujuan pembelian berdasarkan seluruh kriteria objektif seperti misalnya ukuran, berat, harga, atau ukuran perkemasan. Sedangkan yang dimaksud dengan motivasi emosional ialah motivasi yang didasarkan kriteria pribadi atau secara subyektif, seperti kebanggaan, ketakutan, perasaan atau status.

Persepsi kualitas menurut pendapat Aaker (2017) ialah persepsi pelanggan terhadap keseluruhan kualitas atau keunggulan atau layanan berkenaan dengan maksud yang diharapkan. Kesan kualitas tidak dapat diatur sesuai objektif, karena kualitas ini merupakan persepsi dan juga karena melibatkan apa yang penting buat para pelanggan.
Dimensi persepsi kualitas mengacu pada pendapat Durianto dalam Fadhilah (2015), terbagi tujuh, yaitu 1). Kinerja: yang melibatkan berbagai karakteristik operasional utama. 2). Karateristik produk: yang dikenal dengan feature merupakan bagian-bagian tambahan dari produk. 3). Kesesuaian dengan spesifikasi: merupakan pandangan mengenai kualitas dari proses manufaktur (tidak ada cacat dari pabrik) sesuai dengan spesifikasi yang telah ditentukan dan teruji. 4) Keandalan: merupakan konsistensi dan kinerja yang dihasilkan suatu produk dari suatu pembelian ke pembeli berikutnya. 5). Ketahanan: mencerminkan umur ekonomis dari produk. 6) Pelayanan: mencerminkan kemampuan memberikan pelayanan pada produk tersebut. 7) Hasil: mengarah pada kualitas yang dirasakan yang melibatkan enam dimensi sebelumnya. Jika suatu perusahaan tidak dapat menghasilkan hasil akhir produk yang baik maka kemungkinan produk tersebut tidak akan mempunyai atribut kualitas yang baik.

Kotler dan Keller (2009) menjelaskan minat beli ialah perilaku yang muncul sebagai respon terhadap objek dimana konsumen menunjukkan keinginannya untuk melakukan pembelian. Menurut Durianto (2013), minat beli merupakan keinginan yang muncul 
dalam diri konsumen terhadap sebuah produk karena dampak dari suatu proses pengamatan dan pembelajaran konsumen tersebut terhadap sebuah produk.

Menurut Ferdinand (2011), minat beli dapat diidentifikasi melalui indikator-indikator sebagai berikut; 1). Minat transaksional, yaitu kecenderungan seseorang untuk membeli produk. 2). Minat referensial, yaitu kecenderungan seseorang untuk mereferensikan produk kepada orang lain. 3). Minat preferensial, yaitu minat yang menggambarkan perilaku seseorang yang memiliki preferensi utama pada produk tersebut. Preferensi ini hanya dapat diganti jika terjadi sesuatu dengan produk preferensinya. 4). Minat eksploratif, yaitu menggambarkan perilaku seseorang yang selalu mencari informasi mengenai produk yang diminatinya dan mencari informasi untuk mendukung sifat-sifat positif dari produk tersebut.

Teori Perilaku Beralasan atau Theory of Reasoned Action (TRA) pertama kali diperkenalkan oleh Martin Fishbein dan Ajzen (Jogiyanto dalam Santoso dan Yanti, 2015). Teori ini menghubungkan antara keyakinan (belief), sikap (attitude), kehendak (intention) dan perilaku (behavior). Kehendak dapat menjadi prediksi terbaik dari suatu perilaku. Artinya jika ingin mengetahui apa yang akan dilakukan seseorang, cara terbaik adalah mengetahui kehendak orang tersebut.

Menurut Jogiyanto dalam Santoso dan Yanti (2015) seseorang dapat membuat pertimbangan berdasarkan alasan-alasan yang sama sekali berbeda (tidak selalu berdasarkan kehendak). Konsep penting dalam teori ini adalah fokus perhatian (salience), yaitu mempertimbangkan sesuatu yang dianggap penting. Kehendak (intention) ditentukan oleh sikap dan norma subyektif.

Teori perilaku beralasan diperluas dan dimodifikasi oleh Ajzen (Jogiyanto dalam Santoso dan Yanti, 2015) dan dinamai Teori Perilaku Terencana (Theory of Planned Behavior). Inti teori ini mencakup tiga hal yaitu; yaitu keyakinan tentang kemungkinan hasil dan evaluasi dari perilaku tersebut (behavioral beliefs), keyakinan tentang norma yang diharapkan dan motivasi untuk memenuhi harapan tersebut (normative beliefs), serta keyakinan tentang adanya faktor yang dapat mendukung atau menghalangi perilaku dan kesadaran akan kekuatan faktor tersebut (control beliefs).

Singkatnya teori Perilaku Terencana mengatakan bahwa seseorang akan melakukan suatu perbuatan apabila ia memandang perbuatan itu positif dan bila ia percaya bahwa orang lain ingin agar 
ia melakukannya. Berikut ini gambar

kerangka pemikiran.

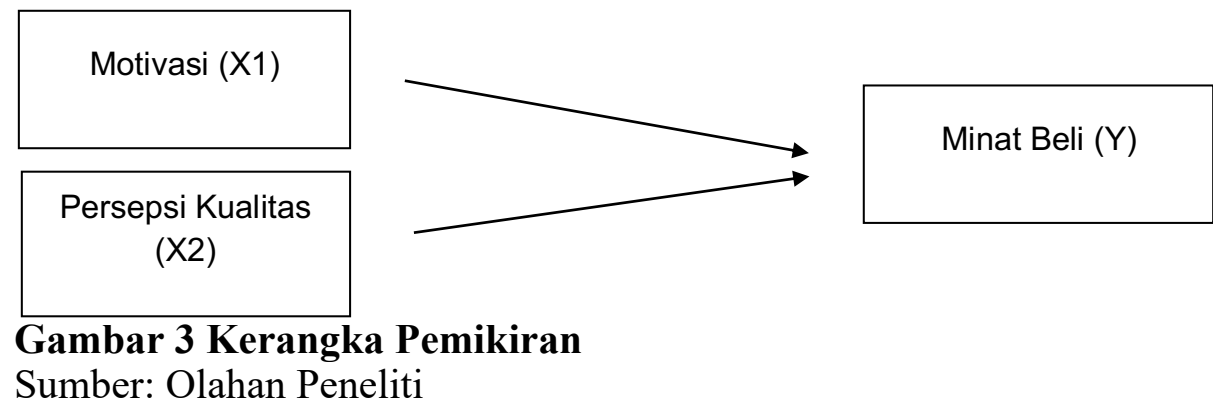

Berdasarkan gambar di atas, terlihat terdapat dua variabel bebas (X), yaitu motivasi (X1) dan persepsi kualitas (X2) yang memengaruhi variabel terikat (Y). Terlihat dua arah panah dari variabel bebas mengarah kepada minat beli sebagai variabel terikat. Berikut ini penjelasan mengenai metode penelitian.

\section{METODE PENELITIAN}

Metode yang digunakan dalam penelitian ini adalah metode penelitian kuantitatif penelitian deskriptif dan verifikatif. Penelitian deskriptif dilakukan untuk menjawab rumusan masalah pertama dan kedua, yaitu untuk mengetahui gambaran tentang motivasi, persepsi kualitas dan minat beli mahasiswa perguruan tinggi swasta di Tangerang. Penelitian verifikatif pada penelitian ini dilakukan untuk mengetahui pengaruh motivasi dan persepsi kualitas terhadap minat beli mahasiswa universitas swasta di Tangerang.

Sugiyono (2012) menjelaskan bahwa penelitian deskriptif adalah suatu penelitian yang dilakukan untuk mengetahui nilai variabel mandiri, baik satu variabel atau lebih (independent) tanpa membuat perbandingan, atau menghubungkan antara satu dengan variabel yang lain. Penelitian verifikatif menurut Arikunto (2010) adalah pada dasarnya ingin menguji kebenaran dari suatu hipotesis yang dilaksanakan melalui pengumpulan data dilapangan, dimana pengujian hipotesis tersebut menggunakan perhitungan statistik.

Pada penelitian ini yang diuji ialah apakah ada pengaruh dan seberapa besar pengaruh motivasi terhadap minat beli laptop Apple dan apakah ada pengaruh dan seberapa besar pengaruh persepsi kualitas terhadap minat beli laptop Apple pada 
mahasiswa. Adapun sebagai variabel bebas adalah motivasi (X1) dan persepsi kualitas (X2). Sedangkan

Operasional variabel yang diteliti terbagi menjadi dua, yaitu variabel bebas dan variabel terikat. Definisi operasional untuk masingmasing variabel sebagai berikut: Variabel bebas / X (independent variabel) adalah variabel yang memengaruhi variabel terikat / Y (dependent variabel). Dalam penelitian ini yang menjadi variable sebagai variabel terikat adalah minat beli laptop (Y).

bebas ialah motivasi dan persepsi kualitas. Adapun yang dimaksud dengan variabel terikat / Y (dependent variabel) ialah variabel yang dipengaruhi oleh variabel bebas. Dalam penelitian ini yang menjadi variabel terikat ialah minat beli. Berikut ini tabel operasional variabel penelitian.

Tabel 1

Operasional Variabel Penelitian

\begin{tabular}{|c|c|c|c|}
\hline Variabel & Definisi & Dimensi & Indikator \\
\hline \multirow[t]{2}{*}{$\begin{array}{l}\text { Motivasi } \\
\text { (X1) }\end{array}$} & \multirow{2}{*}{$\begin{array}{l}\text { Motivasi } \\
\text { merupakan } \\
\text { kekuatan } \\
\text { pendorong dalam } \\
\text { diri seseorang } \\
\text { yang memaksanya } \\
\text { untuk melakukan } \\
\text { suatu tindakan } \\
\text { (Schiffman dan } \\
\text { Wisenblit, 2014). }\end{array}$} & $\begin{array}{ll}\text { - } & \text { Motivasi } \\
\text { Rasional } \\
\text { (Yusa, 2015) }\end{array}$ & $\begin{array}{ll}\text { - } & \text { Harga } \\
\text { - } & \text { Ketersediaan } \\
\text { produk } \\
\text { - } \\
\text { Ukuran } \\
\text { produk }\end{array}$ \\
\hline & & $\begin{array}{ll}- & \text { Motivasi } \\
\text { Emosional } \\
\text { (Yusa, 2015) }\end{array}$ & $\begin{array}{l}\text { - Penampilan } \\
\text { produk } \\
\text { - Rasa senang } \\
\text { - Rasa bangga }\end{array}$ \\
\hline $\begin{array}{l}\text { Persepsi } \\
\text { kualitas } \\
\text { (X2) }\end{array}$ & $\begin{array}{l}\text { Persepsi kualitas } \\
\text { produk (atau jasa) } \\
\text { didasarkan pada } \\
\text { berbagai isyarat } \\
\text { informasi dari } \\
\text { yang mereka } \\
\text { asosiasikan } \\
\text { dengan produk. } \\
\text { Beberapa isyarat } \\
\text { ini instrinsik }\end{array}$ & $\begin{array}{ll}\text { - } & \text { Kinerja } \\
\text { - } & \text { Ketahanan } \\
\text { - } & \text { Karakteristik } \\
\text { - } & \text { Hasil } \\
& \text { (Fadhilah, } \\
& 2015)\end{array}$ & $\begin{array}{ll}\text { - } & \text { Kinerja } \\
\text { produk } \\
\text { - } & \text { Daya tahan } \\
\text { produk } \\
\text { - } & \text { Fitur yang } \\
\text { membedakan } \\
\text { produk } \\
\text { dengan merek } \\
\text { lain }\end{array}$ \\
\hline
\end{tabular}

Communication X, Nomor 1, April 2019 


\begin{tabular}{|c|c|c|c|}
\hline Variabel & Definisi & Dimensi & Indikator \\
\hline & $\begin{array}{l}\text { untuk produk atau } \\
\text { jasa dan juga } \\
\text { ekstrinsik. Baik } \\
\text { secara tunggal } \\
\text { atau bersama- } \\
\text { sama, isyarat } \\
\text { tersebut } \\
\text { menyediakan } \\
\text { dasar } \\
\text { persepsi terhadap } \\
\text { kualitas produk } \\
\text { dan jasa, isyarat- } \\
\text { isyarat intrinsik } \\
\text { lebih } \\
\text { memperhatikan } \\
\text { pada karakteristik } \\
\text { fisik dari produk } \\
\text { itu sendiri, seperti } \\
\text { ukuran, warna, } \\
\text { rasa atau aroma } \\
\text { (Shiffman dan } \\
\text { Kanuk, 2010) }\end{array}$ & & $\begin{array}{l}\text { Hasil akhir } \\
\text { produk yang } \\
\text { diharapkan } \\
\text { konsumen }\end{array}$ \\
\hline $\begin{array}{c}\text { Minat beli } \\
\text { (Y) }\end{array}$ & $\begin{array}{l}\text { Minat beli } \\
\text { merupakan } \\
\text { perilaku yang } \\
\text { muncul sebagai } \\
\text { respon terhadap } \\
\text { objek yang } \\
\text { menunjukkan } \\
\text { keinginan } \\
\text { konsumen untuk } \\
\text { melakukan } \\
\text { pembelian. } \\
\text { (Kotler \& } \\
\text { Keller,2009) }\end{array}$ & $\begin{array}{ll}\text { - } & \text { Minat } \\
\text { preferensial } \\
\text { - } & \text { Minat } \\
\text { transaksional } \\
\text { - } & \text { Minat } \\
\text { eksploratif } \\
\text { (Ferdinand, } \\
\text { 2011) }\end{array}$ & $\begin{array}{l}\text { - Lebih } \\
\text { memilih } \\
\text { produk } \\
\text { tersebut } \\
\text { dibandingkan } \\
\text { merek lain } \\
\text { - Tertarik untuk } \\
\text { mencoba } \\
\text { produk } \\
\text { - Mencari } \\
\text { informasi } \\
\text { mengenai } \\
\text { produk } \\
\text { Mudah } \\
\text { menemukan } \\
\text { informasi }\end{array}$ \\
\hline
\end{tabular}




\begin{tabular}{|c|c|c|c|}
\hline Variabel & Definisi & Dimensi & Indikator \\
\hline & & & $\begin{array}{l}\text { mengenai } \\
\text { produk } \\
\text { Mencari } \\
\text { informasi } \\
\text { positif tentang } \\
\text { produk }\end{array}$ \\
\hline
\end{tabular}

Sumber: Olahan Peneliti

Menurut Sugiyono (2017) populasi adalah wilayah generalisasi yang terdiri atas; obyek/subyek yang mempunyai kualitas dan karakteristik tertentu yang ditetapkan oleh peneliti untuk dipelajari dan kemudian ditarik kesimpulannya. Dalam penelitian ini, yang menjadi populasi adalah Perguruan Tinggi Swasta (PTS) di Tangerang, yaitu UMN Fakultas Seni dan Desain. Teknik pengambilan sampel yang digunakan pada penelitian ini adalah purposive sampling dengan karakteristik responden adalah mahasiswa yang belum memiliki laptop merek Apple. Didapatkan jumlah sampel sebanyak 100 responden. Waktu penyebaran kuesioner ini adalah selama bulan Februari 2019.

Pengumpulan data primer didapatkan dengan menyebarkan kuesioner kepada responden. Menurut Sugiyono (2012) data primer ialah data yang didapat langsung dari sumbernya, yaitu dalam hal ini ialah responden.
Selain data primer dalam penelitian diperlukan pengumpulan data sekunder. Data sekunder ini merupakan data yang sifatnya mendukung keperluan data primer dan juga literatur utama tentang motivasi, persepsi kualitas, dan minat beli yang bisa didapatkan dari berbagai sumber, seperti data internal perusahaan, internet, buku-buku, literatur.

Teknik analisis data dalam penelitian ini menggunakan regresi dimana untuk meramalkan pengaruh data satu dengan data lainnya. Uji yang dilakukan, yaitu uji T dan uji F. Uji $\mathrm{T}$ dilakukan untuk menguji koefisien regresi secara parsial utuk melihat ada tidaknya pengaruh suatu variabel bebas terhadap variabel terikat. Jadi, melihat apakah ada pengaruh antara motivasi dan persepsi kualitas terhadap minat beli mahasiswa terhadap laptop merek Apple.

Uji F dilakukan untuk melihat koefisien regresi secara bersama- 
sama apakah terdapat pengaruh yang signifikan dari semua variabel independen secara bersama-sama (motivasi dan persepsi kualitas) terhadap variabel dependen (minat beli).

Koefisien determinasi digunakan dalam penelitian ini untuk mencari seberapa besar persentase pengaruh antara motivasi terhadap minat beli, antara persepsi kualitas terhadap minat beli. Di bawah ini penjelasan mengenai hasil dan pembahasan.

\section{HASIL DAN PEMBAHASAN}

Berikut ini tabel uji T hasil pengolahan data melalui SPSS.

Tabel 2

Uji T

Coefficients $^{\mathrm{a}}$

\begin{tabular}{|c|c|c|c|c|c|c|}
\hline & \multirow[b]{2}{*}{ Model } & \multicolumn{2}{|c|}{$\begin{array}{l}\text { Unstandardized } \\
\text { Coefficients }\end{array}$} & \multirow{2}{*}{$\begin{array}{c}\text { Standardized } \\
\text { Coefficients }\end{array}$} & \multirow[b]{2}{*}{$\mathrm{t}$} & \multirow[b]{2}{*}{ Sig. } \\
\hline & & B & Std. Error & & & \\
\hline \multirow[t]{3}{*}{1} & (Constant) & .649 & 1.892 & & .343 & .732 \\
\hline & $\mathrm{X} 1$ & .241 & .060 & .396 & 4.033 & .000 \\
\hline & $\mathrm{X} 2$ & .248 & .060 & .406 & 4.127 & .000 \\
\hline
\end{tabular}

Sumber: Olahan SPSS

Uji T (Uji Parsial)

Uji $t$ pertama untuk mengetahui apakah variabel motivasi berpengaruh positif terhadap variabel minat beli. Berdasarkan hasil uji $t$ pada tabel 2, diketahui variabel motivasi (X1) terlihat memiliki nilai signifikansi (sig) sebesar 0,000 dan nilai $t$ hitung adalah 4,033. Nilai signifikansi tersebut $\alpha<$ dari 0,05 yang artinya sudah signifikan.
Hasil t hitung 4,033 > hasil $\mathrm{t}$ tabel 1,984 yang dapat disimpulkan bahwa motivasi mempunyai pengaruh positif terhadap minat beli. Kemudian, uji $\mathrm{t}$ yang kedua adalah untuk mengetahui apakah variabel. Berdasarkan hasil uji t pada tabel 2, diketahui variabel persepsi kualitas (X2) terlihat memiliki nilai signifikansi (sig) sebesar 0,000 dan 
nilai $\mathrm{t}$ hitung adalah 4,127. Nilai signifikansi tersebut $\alpha<$ dari 0,05 yang artinya sudah signifikan. Hasil $\mathrm{t}$ hitung 4,127 > t tabel 1,984 sehingga dapat disimpulkan bahwa persepsi kualitas mempunyai pengaruh positif terhadap minat beli. Berikut ini tabel Uji F.

Tabel 3

Uji F (Simultan)

ANOVA ${ }^{\mathrm{a}}$

\begin{tabular}{|c|c|c|c|c|c|c|}
\hline & Model & $\begin{array}{l}\text { Sum of } \\
\text { Squares }\end{array}$ & Df & Mean Square & $\mathrm{F}$ & Sig. \\
\hline \multirow[t]{3}{*}{1} & Regression & 610.674 & 2 & 305.337 & 60.455 & $.000^{\mathrm{b}}$ \\
\hline & Residual & 489.916 & 97 & 5.051 & & \\
\hline & Total & 1100.590 & 99 & & & \\
\hline
\end{tabular}

Sumber: Olahan SPSS

Hasil uji $F$ dari tabel 3 diketahui nilai signifikansi untuk pengaruh variabel motivasi (X1) dan variabel persepsi kualitas (X2) secara simultan terhadap variabel minat beli (Y) adalah sebesar 0,000. Nilai signifikansi tersebut $\alpha<$ dari 0,05 yang artinya sudah signifikan. Sementara itu, nilai dari $\mathrm{F}$ hitung adalah sebesar 60,455. Hasil dari F tabel adalah sebesar 3,09 dari hal tersebut dapat disimpulkan bahwa nilai $\mathrm{F}$ hitung $>\mathrm{F}$ tabel, dimana $60,455>3,09$, sehingga terdapat pengaruh variabel motivasi (X1) dan variabel persepsi kualitas (X2) secara simultan terhadap variabel minat beli. Berikut ini tabel 4 uji koefisien determinasi.

Tabel 4

Uji Koefisien Determinasi $\left(\mathbf{R}^{2}\right)$

Model Summary

\begin{tabular}{|l|l|l|l|l|}
\hline Model & $\mathrm{R}$ & R Square & $\begin{array}{c}\text { Adjusted R } \\
\text { Square }\end{array}$ & $\begin{array}{c}\text { Std. Error of the } \\
\text { Estimate }\end{array}$ \\
\hline
\end{tabular}




\begin{tabular}{|l|r|r|r|r|}
\hline 1 & $.745^{\mathrm{a}}$ & .555 & .546 & 2.247 \\
\hline
\end{tabular}

Sumber: Olahan SPSS

Uji koefisien determinasi dilakukan untuk mengetahui seberapa besar pengaruh variabel bebas, dalam penelitian ini adalah motivasi dan persepsi Kualitas, terhadap variabel terikat, dalam penelitian ini adalah minat beli. Hasil uji determinasi yang dapat dilihat pada tabel 4 menujukan nilai $R$ sebesar 0,555 dimana pengaruh variabel motivasi dan persepsi secara simultan terhadap variabel minat beli adalah $55,5 \%$, sedangkan $44,5 \%$ sisanya dijelaskan oleh variasi variabel lain yang tidak dijelaskan dalam penelitian ini.

$$
\text { Motivasi adalah suatu }
$$

dorongan yang membuat konsumen untuk membeli dan itu dipicu oleh tekanan psikologis yang disebabkan oleh tidak terpenuhinya suatu kebutuhan, kemudian seorang individu berusaha secara sadar dan tidak sadar untuk mengurangi tekanan ini melalui pemilihan apa yang menjadi tujuannya dan perilaku selanjutnya yang mereka harapkan akan memenuhi kebutuhannya dan dengan sesuatu yang membebaskan dari tekanan yang mereka rasakan (Schiffman dan Wisenblit, 2014).

Dalam uji $t$ yang sudah dilakukan, motivasi secara individu sudah memiliki pengaruh yang signifikan dan positif terhadap minat beli laptop Apple. Hal tersebut terlihat dari motivasi yang memiliki nilai signifikansi (sig) sebesar 0,000 dan nilai t hitung adalah 4,033 . Nilai signifikansi tersebut alpha $<$ dari 0,05 yang artinya sudah signifikan serta hasil $\mathrm{t}$ hitung 4,033 > hasil $\mathrm{t}$ tabel 1,984 yang artinya sudah positif.

Dengan demikian sebagai produsen laptop, Apple dapat lebih memproduksi sebuah laptop yang dapat membuat dorongan kepada konsumen untuk memiliki minat beli yang lebih tinggi terhadap produknya, seperti memberikan harga yang sesuai standar dari sebuah merek Apple dengan tetap mempertahankan atau bahkan meningkatkan kualitasnya agar harga yang tawarkan dapat diterima konsumen, tampilan produk yang lebih elegan, berkelas sehingga konsumen bangga dan merasa senang saat memilikinya, serta memperhatikan ketersediaan dan kemudahan konsumen untuk memperoleh produknya di pasaran.

Persepsi kualitas menurut pendapat Aaker (2017) ialah persepsi pelanggan terhadap keseluruhan kualitas atau keunggulan atau layanan berkenaan dengan maksud yang diharapkan. Kesan kualitas tidak dapat diatur sesuai objektif, karena kualitas ini merupakan persepsi dan 
juga karena melibatkan apa yang penting buat para pelanggan. Dalam uji t yang sudah dilakukan, persepsi kualitas secara individu sudah memiliki pengaruh yang signifikan dan positif terhadap minat beli laptop Apple. Hal tersebut terlihat dari terlihat memiliki nilai signifikansi (sig) sebesar 0,000 dan nilai t hitung adalah 4,127. Nilai signifikansi tersebut alpha $<$ dari 0,05 yang artinya sudah signifikan serta hasil $\mathrm{t}$ hitung 4,127 > t tabel 1,984 yang artinya sudah positif.

Melihat hasil tersebut, Apple sebagai produsen laptop dapat meningkatkan produk-produknya dari segi kinerja hardware maupun software. Laptop yang memiliki daya tahan produk secara keseluruhan yang baik dan baterai yang dapat bertahan lama serta karakteristik yang dapat dilihat dari fitur-fitur yang tersedia pada laptop dapat ditingkatkan dengan ciri khas Apple. Sehingga membuat calon konsumen merasa bahwa laptop Apple merupakan laptop yang mereka butuhkan.

Selanjutnya, setelah dilakukan uji $\mathrm{F}$ didapatkan hasil bahwa variabel motivasi dan persepsi kualitas memiliki pengaruh secara simultan atau bersama-sama terhadap variabel minat beli karena memiliki signifikansi sebesar 0,000 dengan nilai signifikansi tersebut alpha $<$ dari 0,05 yang artinya sudah signifikan. Sementara itu, nilai dari $\mathrm{F}$ hitung adalah sebesar 60,455 yang sudah lebih besar dari hasil $\mathrm{F}$ tabel yang sebesar 3,09. Secara bersama-sama, presentase pengaruh motivasi dan persepsi Kualitas terhadap Minat Beli laptop Apple sebesar 55,5\%.

\section{SIMPULAN}

Berdasarkan hasil dari pengujian hipotesis yang mencakup uji $t$, uji $f$, dan uji koefisien determinasi yang sudah dilakukan dalam penelitian ini, maka berikut kesimpulan dari penelitian ini adalah motivasi berpengaruh signifikan terhadap minat beli laptop merek Apple pada mahasiswa perguruan tinggi swasta di Tangerang. Persepsi kualitas berpengaruh signifikan terhadap minat beli laptop merek Apple pada mahasiswa perguruan tinggi swasta di Tangerang. Motivasi dan persepsi kualitas secara simultan berpengaruh signifikan terhadap minat beli laptop merek Apple pada mahasiswa perguruan tinggi swasta di Tangerang.

\section{DAFTAR PUSTAKA}

Aaker, D. A. 2017. Manajemen Ekuitas Brand. Jakarta: Mitra Utama.

Arikunto, S. 2010. Metode Penelitian. Jakarta: PT. Rineka Cipta.

Durianto, D. 2013. Strategi Menaklukan Pasar Melalui Riset Ekuitas dan 
Perilaku Merek (cet. ke-10). Jakarta: PT Gramedia Pustaka Utama. Ferdinand, A. 2011. Pengembangan Minat Beli Merek Ekstensi. Semarang: Badan Penerbit Universitas Diponegoro.

Kotler, P and Keller, K. L. 2009. Manajemen Pemasaran. Jilid I. Edisi ke 13. Jakarta: Erlangga

Schiffman, L. G., \& Wisenblit, J. 2014. Consumer behavior global edition. Boston (Mass): Pearson Education.

Sugiyono. 2012. Metode Penelitian Kuantitatif Kualitatif dan $R \& D$. Bandung: Alfabeta.

Apple Surpassed ASUS, recording 9.6\% Market Share in 2017 Global Notebook Market, Says TrendForce. Diakses 27 Juli 2018, dari https://press.trendforce.com/p ress/20180212-3065.html

Best Laptop Brands of 2017 with Trusted Models and Reviews. (2017, 28 Oktober). Diakses 14 November 2017, dari https://www.atulhost.com/bes t-laptop-brands

Fadhilah, A. 2015. Pengaruh Kesadaran Merek, Asosiasi Merek, Persepsi Kualitas Dan Loyalitas Merek Terhadap Proses Pengambilan Keputusan Pembelian Sepeda Motor Yamaha V-Ixion. Jurnal MIX, Volume VI, No. 2, $188-205$
2017. Metode Penelitian

Kuantitatif, Kualitatif dan $R \& D$. Bandung: Alfabeta.

Wibowo, S \& Supriadi, D. 2013. Ekonomi Mikro Islam. Bandung: Pustaka Setia

Williams, B. K., \& Stacey, C. S. 2011. Using Information Technology, a Practical Introduction to Computer \& Communications. New York: McGraw-Hill.

\section{Sumber lain:}

Nielsen. 2017. The New Trends Among Indonesia's Netizens.

R. H. 2017, November 12). 10 Best Laptop Brands $2017 \quad$ Unbiased Reviews \& Performance Report. Diakses 14 November 2017, dari http://techlogitic.net/bestlaptop-brands/

Santoso, D. Yanti, H, B. 2015. Pengaruh Perilaku Tidak Jujur Dan Kompetensi Moral Terhadap Kecurangan Akademik (Academic Fraud) Mahasiswa Akuntansi. Media Riset Akuntansi, Auditing \& Informasi Vol. 15 No. 1, 1-16 Yusa, V. D. 2015. Pengaruh Motif Rasional Dan Motif Emosional Terhadap Keputusan Pembelian Ponsel Blackberry Di Bandar 
Lampung. DERIVATIF Vol.

9 No. 2, 97-111 